\title{
Unique case of granulomatous arteritis in a grey mouse lemur (Microcebus murinus) - first case description
}

\author{
Nicole Cichon ${ }^{1}$, Karen Lampe ${ }^{1}$, Felix Bremmer ${ }^{2}$, Tamara Becker ${ }^{1}$, and Kerstin Mätz-Rensing ${ }^{1}$ \\ ${ }^{1}$ German Primate Center, Kellnerweg 4, 37077 Göttingen, Germany \\ ${ }^{2}$ Georg-August-Universität, Universitätsmedizin Göttingen, Robert Kochstr. 40, 37075 Göttingen, Germany
}

Correspondence to: Kerstin Mätz-Rensing (kmaetz@dpz.eu)

Received: 31 January 2017 - Revised: 8 March 2017 - Accepted: 9 March 2017 - Published: 3 April 2017

\begin{abstract}
Overall, diseases of the vascular system are rarely observed entities among nonhuman primates that are commonly associated with systemic infections, septicemia or bacteremia. Rhesus monkeys infected with simian immunodeficiency virus (SIV) may develop a chronic occlusive arteriopathy of unknown etiology in late stages of the disease. This SIV associated arteriopathy is the only well-known specific vascular entity described in nonhuman primates. We herein report a unique case of granulomatous arteritis in a grey mouse lemur affecting multiple organs, which is not comparable to other disease entities formerly described in nonhuman primates. The features of the entity most closely resemble disseminated visceral giant cell arteritis in humans. A concise description of the disease is given, and the differential diagnoses are discussed. An idiopathic pathogenesis is suspected.
\end{abstract}

\section{Introduction}

Grey mouse lemurs (Microcebus murinus) are primates belonging to the suborder Strepsirrhini and infraorder Lemuriformes (Fig. 1). Within the Lemuriformes they belong to the family Cheirogaleidae, a group that includes the smallest primates in the world. Among this family the grey mouse lemur is a small-bodied lemur with an average weight of $60 \mathrm{~g}$. Like all other members of the family Cheirogaleidae, grey mouse lemurs are nocturnal and arboreal. Mouse lemurs are important animal models in biomedical and basic biological research. They are used as an animal model for cerebral aging and neurodegenerative diseases (Fischer and Ausstad, 2011; Verdier et al., 2015). Their high species diversity makes them interesting and important for evolutionary research (Zimmermann and Radespiel, 2014). Meanwhile, their genome is completely sequenced by the Broad Institute (GenBank accession number ABDC00000000). Mouse lemurs in captivity suffer most frequently from chronic nephritis and renal insufficiency. This syndrome is accompanied by hormone imbalances characterized by increased cortico- and medulloadrenal secretion most probably induced by stress factors occurring in captivity (Perret, 1982). Vasculitis of any type has not been reported in mouse lemurs. We describe here a unique case of granulomatous vasculitis, which shares several features with an extremely rare entity in humans called disseminated visceral giant cell arteritis (DVGCA). DVGCA is an unusual type of extracranial giant cell arteritis involving arteries and arterioles of various organs with unknown pathogenesis. The entity was first described in 1978 by Lie and is only reported in humans. The type of vessels which are principally involved, the presence or absence of giant cells, vascular fibrinoid necrosis and eosinophilic infiltrates may help to distinguish the different vasculitis types (Lie, 1978; Jennette et al., 2013). The differences between the reported disease and other forms of vasculitis are discussed in detail.

\section{Case report}

Within a captive, indoor-housed colony of grey mouse lemurs, a 6-year-old intact male animal presented with acute onset of clinical symptoms including hematuria, reduced general condition, weight loss and inappetence. Physical examination revealed a poor body condition and a bloodsmeared coat in the genital region. Injuries were not detected; thus, an acute hemorrhagic cystitis was suspected. Therapy consisted of parenteral application of enrofloxacin, meloxi- 


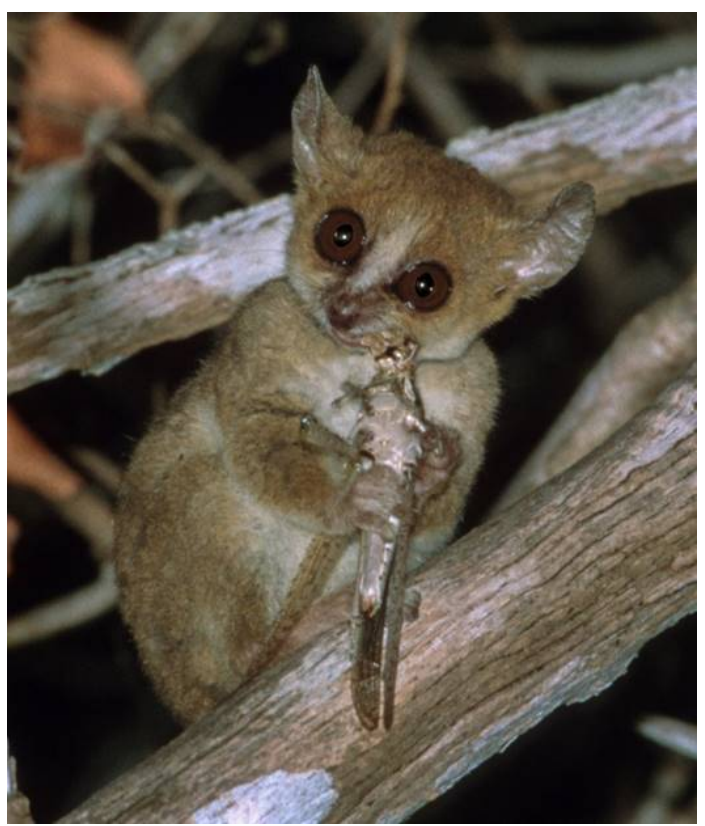

Figure 1. Grey mouse lemur (picture by Dr. Manfred Eberle).

cam, fluid therapy, and vitamins and supplementary food as supportive care. Two days after initial presentation, the lemur was found dead.

\section{Gross pathology and histology}

At necropsy, hemorrhages were found within several organs. They were most prominent within lung parenchyma and urinary bladder and less severe within the renal pelvis and the subcutis. Furthermore, the spleen was enlarged.

The main histologic finding within the lung parenchyma was a severe granulomatous inflammation of small- and medium-sized arteries (Fig. 2a-d). The intima of affected vessels showed mild fibrinoid necrosis and proliferation. The tunica media and adventitia were heavily infiltrated by a mixed-cellular infiltrate. Giant cells of foreign body and Langhans type represented the dominant cell type. Eosinophils, a type of leucocytes, were also present in a moderate number. The lesions were accompanied by alveolar hemorrhage and histiocytosis. Vascular inflammation of milder degree was found within the kidneys and the liver. At these latter sites, giant cells were absent. Large foci of hemorrhages and perivascularly accentuated mixed-cellular inflammation were observed in the urinary bladder. Reactive extramedullary hematopoiesis was prominent within the spleen and, to a lesser degree, within the liver. Furthermore, a mild lymphocytic interstitial myocarditis was evident. The aorta was unremarkable.

In order to detect the cause of the granulomatous vasculitis and to reveal possible infectious pathogens like mycobacteria, fungi or even parasites, several histochemical stains were performed. Giemsa, Ziehl-Neelsen and Grocott staining as well as periodic acid-Schiff (PAS) reaction were negative. A routinely performed bacteriologic investigation of all organ systems revealed no pathogenic microorganisms within the tissues. Furthermore, lung tissue was tested by nested and real-time polymerase chain reaction (PCR) for the presence of a viral infection with influenza A or B, enterovirus, adenovirus, paramyxovirus, picornavirus and respiratory syncytial virus (RSV). There was no evidence of a viral or bacterial infection of the respiratory tract. Thus, the cause of disease remains unclear.

\section{Discussion}

A unique case of an idiopathic granulomatous generalized vasculitis in a mouse lemur is described. Inflammation of the blood vessel wall can be induced by several infectious agents in the course of bacteremia or septicemia. In the present case, no specific microorganisms were detectable by routine microbiological investigations. Furthermore, most important infectious diseases inducing granulomatous inflammation such as tuberculosis, leprosy, aspergillosis and leishmaniasis could be ruled out histologically by special stains and by bacteriologic investigation of tissue samples. No evidence existed of a foreign body reaction or foreign body disease by histologic investigation. A drug-induced vasculitis could be excluded as well because the animal never received drugs like propylthiouracil, methimazole, sulfasalazine, Dpenicillamine or minocycline capable of inducing microscopic polyangiitis. Finally, the observed disease is not comparable with a well-known arteriopathy, a unique entity of vascular diseases occurring in immunosuppressed simian immunodeficiency virus (SIV)-infected rhesus monkeys, which is characterized by intimal and medial thickening and fibrosis occluding the vessel lumen (Chalifoux et al., 1992). Given that evidence of any form of immunosuppression is lacking in the mouse lemur, an idiopathic autoimmune or allergic disorder is suspected as the underlying disease in the present case.

Several different forms of idiopathic disseminated giant cell arteritis are well recognized in humans and should be discussed as a differential diagnosis for this case (Table 1).

They mainly differ in their distribution, and a rough classification can be done according to the vessel type involved. In this respect, giant cell arteritis (GCA) and Takayasu's arteritis (TAK) could be excluded, because they mainly affect the aorta and other large-sized vessels, which were not altered in the present case. With the same argumentation, polyarteritis nodosa (PAN), an idiopathic multisystemic necrotizing vasculitis, could also be excluded, because it mainly affects medium-sized vessels and spares lung vasculature. PAN is the only idiopathic vasculitis which has been reported in animals, including dogs, rats, mice, cats, pigs and a cynomolgus macaque (Porter et al., 2003). PAN predominantly af- 


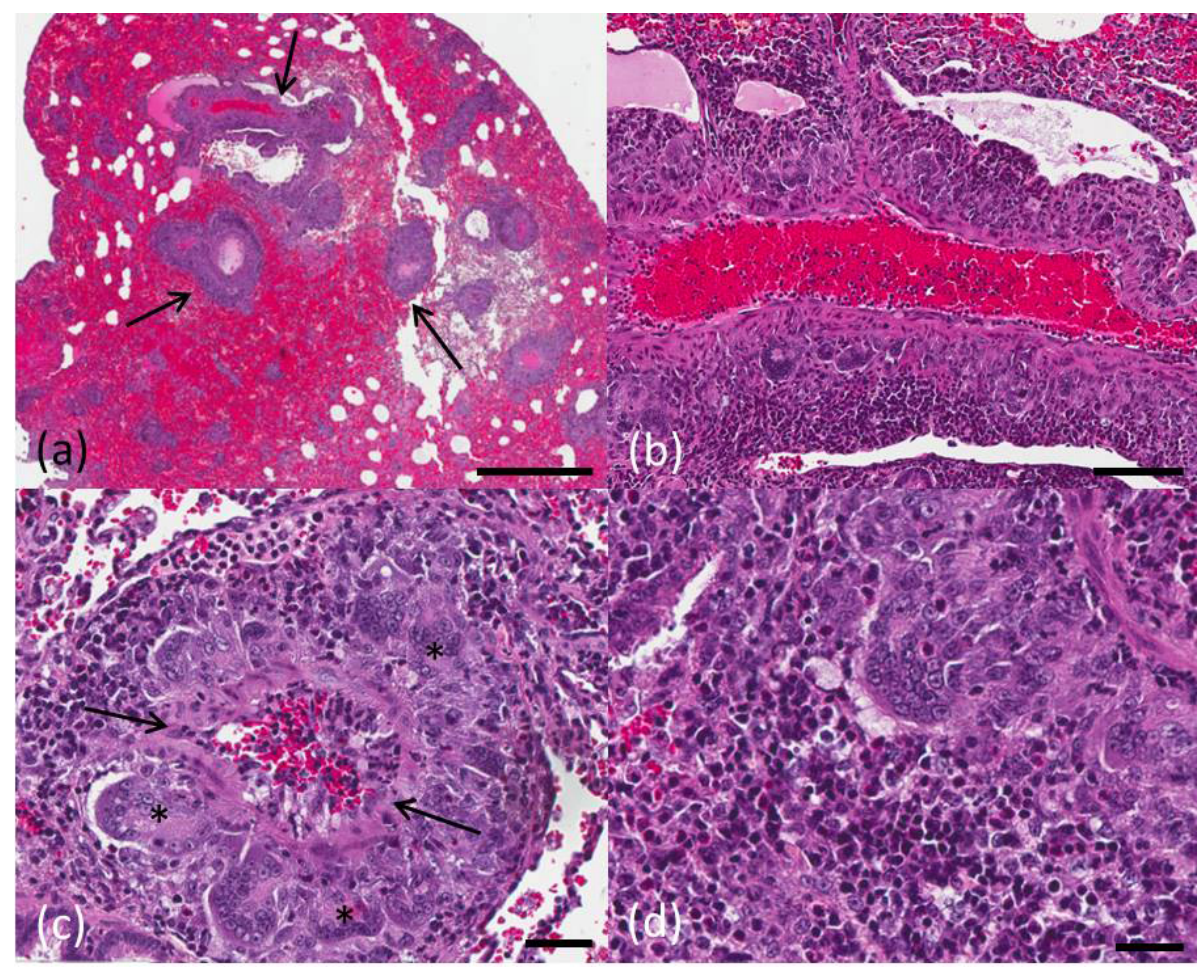

Figure 2. Grey mouse lemur, lung. (a) Perivascularly accentuated distribution pattern of the inflammation (arrows) and severe alveolar hemorrhage, scale bar $1 \mathrm{~mm}$. (b) Granulomatous inflammation around a blood vessel, scale bar $100 \mu \mathrm{m}$. (c) Discreet fibrinoid necrosis of a vessel wall (arrow) accompanied by a severe inflammatory reaction with characteristic giant cells (asterisk), scale bar $40 \mu \mathrm{m}$. (d) Mixed inflammatory cell infiltrate with eosinophils in the vascular periphery, scale bar $30 \mu \mathrm{m}$. Hematoxylin and eosin stain.

fects medium-sized arteries (Jenette et al., 2013). The inflammation is most severe in the kidneys, gastrointestinal tract and heart. The lesions are often polyphasic and segmental within an artery and cause a grossly visible nodular thickening. The inflammatory infiltrates consist predominantly of macrophages and T-lymphocytes (Porter et al., 2003). In the present case, especially the lungs were affected, and there were no nodular lesions typical for PAN. The main differences to the present case exist in the lack of giant cells and the amount of fibrinoid necrosis. For the given reasons PAN was excluded as a possible diagnosis.

Another differential diagnosis is microscopic polyangiitis (MPA), a necrotizing vasculitis predominantly affecting small vessels (arterioles, venules and capillaries). The disease was initially considered a microscopic form of PAN. Glomerulonephritis is a characteristic finding, and granulomatous inflammation is absent (Jenette et al., 2013). The main target organs are the kidneys and lungs, with lesions also observed in the skin, muscles, brain and digestive tract (Iida et al., 2016). The kidneys of this mouse lemur did not reveal glomerulonephritis, and the character of the inflammation was granulomatous. Therefore, this disease was excluded as a differential diagnosis.

The eosinophilic nature of the lesions described in the present case could indicate another form of idiopathic vas- culitis called eosinophilic granulomatosis with polyangiitis (EGPA), formerly known as Churg-Strauss vasculitis. It often involves small- to medium-sized vessels of the respiratory tract and is associated with asthma and allergic rhinitis (Cottin et al., 1999; Groh et al., 2015). As emphasized in the name, the predominance of eosinophils is an essential feature (Jennette et al., 2013). A few eosinophils were detected in the case of the mouse lemur, but giant cells represent the predominant cell type. Furthermore, no symptoms of respiratory impairment were described before death. For these reasons, EGPA is excluded as differential diagnosis.

The described lesion also showed similarities to the entity of granulomatosis with polyangiitis (GPA), previously known as Wegener granulomatosis. GPA usually involves small- to medium-sized vessels of the upper and lower respiratory tract (Wojciechowska et al., 2016). Pauci-immune glomerulonephritis is a common feature (Jennette et al., 2013; Takeuchi et al., 2016), but this lesion was not seen in the present case. Like in the present case, hematuria is a frequent finding. The main histologic criteria are the presence of giant cells, which was a very prominent feature of the present case, and fibrinoid necrosis of vessel walls, which was less obvious. GPA is generally characterized by antineutrophil cytoplasm antibodies (ANCA) (Wojciechowska et al., 2016). Unfortunately, it was not possible to measure ANCA 
Table 1. Relevant differential diagnoses for disseminated visceral giant cell arteritis.

\begin{tabular}{|c|c|c|c|c|c|}
\hline Pathologic entity & $\begin{array}{l}\text { Principle affected } \\
\text { vessel }\end{array}$ & Giant cells & $\begin{array}{l}\text { Fibrinoid } \\
\text { necrosis }\end{array}$ & $\begin{array}{l}\text { Eosinophilic } \\
\text { infiltrates }\end{array}$ & ANCA \\
\hline $\begin{array}{l}\text { Giant cell arteritis, } \\
\text { (GCA) (arteritis } \\
\text { temporalis) }\end{array}$ & $\begin{array}{l}\text { aorta, large systemic } \\
\text { arteries }\end{array}$ & + & \pm & \pm & \\
\hline $\begin{array}{l}\text { Takayasu's arteritis } \\
\text { (TAK) }\end{array}$ & $\begin{array}{l}\text { aorta and aortic arch } \\
\text { branches }\end{array}$ & \pm & - & - & \\
\hline $\begin{array}{l}\text { Polyarteritis nodosa } \\
\text { (PAN) }\end{array}$ & $\begin{array}{l}\text { medium-sized and } \\
\text { small arteries }\end{array}$ & \pm & +++ & +++ & negative \\
\hline $\begin{array}{l}\text { Microscopic polyangi- } \\
\text { itis (MPA) }\end{array}$ & $\begin{array}{l}\text { extracranial small arter- } \\
\text { ies and veins }\end{array}$ & - & +++ & \pm & positive \\
\hline $\begin{array}{l}\text { Eosinophilic granulo- } \\
\text { matosis with polyangi- } \\
\text { itis (Churg-Strauss } \\
\text { vasculitis) (EGPA) }\end{array}$ & $\begin{array}{l}\text { extracranial small arter- } \\
\text { ies and veins, perivas- } \\
\text { cular tissue }\end{array}$ & + & +++ & +++ & positive \\
\hline $\begin{array}{l}\text { Granulomatosis with } \\
\text { polyangiitis (Wegener } \\
\text { granulomatosis) (GPA) }\end{array}$ & $\begin{array}{l}\text { small vessel of upper } \\
\text { respiratory tract, lung, } \\
\text { kidney }\end{array}$ & +++ & +++ & +++ & $\begin{array}{l}\text { positive } \\
\text { c-ANCA }\end{array}$ \\
\hline $\begin{array}{l}\text { Disseminated visceral } \\
\text { giant cell arteritis } \\
\text { (DVGCA) }\end{array}$ & $\begin{array}{l}\text { extracranial small arter- } \\
\text { ies and arterioles }\end{array}$ & +++ & \pm & \pm & negative \\
\hline
\end{tabular}

Legend: -: absent; \pm : present occasionally; +: usually present; +++ : always present (adapted to Lie, 1978, and Jennette et al., 2013).

in the present case to definitely exclude this differential diagnosis.

The pattern and character of the lesions in this lemur were very similar to those described in human cases of DVGCA. Key features of DVGCA in humans are involvement of extracranial arteries and arterioles of several organs (heart, lungs, kidneys, liver, pancreas, stomach, trachea, and occasionally aorta and other large arteries). Histologic similarities are the presence of giant cells, a mixed inflammatory cell infiltrate with eosinophils and, to a lesser extent, fibrinoid necrosis of the vessel walls (Lie, 1978). The inflammatory cell infiltrates predominantly consist of histiocytes, lymphocytes and plasma cells. Microorganisms and foreign bodies are not found. By these characteristics, DVGCA can be distinguished from other necrotizing and granulomatous forms of vasculitis.

The cause of DVGCA is unknown. Hypothetically, it might be linked to bacterial or viral infection, autoimmune disease, hypersensitivity and genetic factors. A human case is reported that clinically responded to immunosuppressive therapy (Kagata et al., 1999; Alguacil-Garcia et al., 1995). To our knowledge, this is the first case of granulomatous vasculitis with striking features similar to disseminated visceral giant cell arteritis in a nonhuman primate.
Data availability. The original data on the postmortem, histological and microbiological examinations can be provided upon request.

Competing interests. The authors declare that they have no conflict of interest.

Acknowledgements. We are especially grateful to F.-J. Kaup. He always gave students and young scientists a chance to gain insight into the work of a pathologist and to gain first-hand experience in scientific research during externships at the German Primate Center. This case report is the result of an externship, and we would like to thank him for his support and continuous discussion on this special case. As always he encouraged the team to work on special disease entities in primate pathology and enabled their publication. Our special thanks go to the pathology team (Wolfgang Henkel, Regine Sammel and Stefanie Wienstroth) and the histology team (Nadine Schminke, Larissa Hummel and Corinna Boike).

Edited by: M. Bleyer

Reviewed by: E. Zimmermann and one anonymous referee 


\section{References}

Alguacil-Garcia, G. F., Moreno-Requena, J., Martinez-Albadalejo, M., Hallal-Hachem, H., Gonzalez-Pina, B., and de Paco-Moya, M.: Idiopathic granulomatous vasculitis: response to immunosuppressive therapy, J. Clin. Pathol., 48, 579-582, 1995.

Chalifoux, L. V., Simon, M. A., Pauley, D. R., MacKey, J. J., Wyand, M. S., and Ringler, D. J.: Arteriopathy in macaques infected with simian immunodeficiency virus, Lab. Invest., 67, 338-349, 1992.

Cottin, V. and Cordier, J.-F.: Churg-Strauss syndrome, Allergy, 54, 535-551, doi:10.1034/j.1398-9995.1999.t01-1-00091.x, 1999.

Fischer, K. E. and Austad, S. N.: The development of small primate models for aging research, ILAR J., 52, 78-88, doi:10.1093/ilar.52.1.78, 2011.

Groh, M., Pagnoux, C., Baldini, C., Bel, E., Bottero, P., Cottin, V., Dalhoff, K., Dunogué, B., Gross, W., Holle, J., Humbert, M., Jayne, D., Jennette J. C., Lazor, R., Mahr, A., Merkel, P. A., Mouthon, L., Sinico, R. A., Specks, U., Vaglio, A., Wechsler, M. E., Cordier, J. F., and Guillevin, L.: Eosinophilic granulomatosis with polyangiitis (Churg-Strauss) (EGPA), Consensus Task Force recommendations for evaluation and management, Eur. J. Intern. Med., 26, 545-553, doi:10.1016/j.ejim.2015.04.022, 2015.

Iida, T., Adachi, T., Tabeya, T., Nakagaki, S., Yabana, T., Goto, A., Kondo, Y., and Kasai, K.: Rare type of pancreatitis as the first presentation of anti-neutrophil cytoplasmic antibodyrelated vasculitis, World J. Gastroenterol., 22, 2383-2390, doi:10.3748/WJG.v22.i7.2383, 2016.

Jennette, J. C., Falk, R. J., Bacon, P. A., Basu, N., Cid, M. C., Ferrario, F., Flores-Suarez, L. F., Gross, W. L., Guillevin, L., Hagen, E. C., Hoffman, G. S., Jayne, D. R., Kallenberg, C. G. M., Lamprecht, P., Langford, C. A., Luqmani, R. A., Mahr, A. D., Matteson, E. L., Merkel, P. A., Ozen, S., Pusey, C. D., Rasmussen, N., Rees, A. J., Scott, D. G. I., Specks, U., Stone, J. H., Takahashi, K., and Watts, R. A.: 2012 Revised International Chapel Hill Consensus Conference Nomenclature of Vasculitides, Arthritis Rheum., 65, 1-11, doi:10.1002/art.37715, 2013.
Kagata, Y., Matsubara, O., Ogata, S., Lie, J. T., and Mark, E. J.: Infantile disseminated giant cell arteritis presenting as sudden infant death, Pathol. Int., 49, 226-230, 1999.

Lie, J. T.: Disseminated visceral giant cell arteritis. Histopathologic description and differentiation from other granulomatous vasculitides, Am. J. Clin. Pathol., 69, 299-305, doi:10.1093/ajcp/69.1.299, 1978.

Perret, M.: Stress-effects in Microcebus murinus, Folia Primatol., 39, 63-114, 1982.

Porter, G. F., Frost, P., and Hubbard, G. B.: Polyarteritis Nodosa in a Cynomolgus Macaque (Macaca fascicularis), Vet. Pathol., 40, 570-573, 2003.

Takeuchi, H., Kuroda, I., Takizawa, I., Aoyagi, T., and Tachibana, M.: Granulomatosis with Polyangiitis (Wegener's Granulomatosis) Accompanied by Dysuria, Case Reports in Urology Volume, 7812875, 3 pp., doi:10.1155/2016/7812875, 2016.

Verdier, J.-M,. Acquatella, I., Lautier, C., Devau, G.,Trouche, S., Lasbleiz, C., and Mestre-Francés, N.: Lessons from the analysis of nonhuman primates for understanding human aging and neurodegenerative diseases, Front. Neurosci., doi:10.3389/fnins.2015.00064, 2015.

Wojciechowska, J., Krajewski, W., Krajewski, P., and Kręcicki, T.: Granulomatosis with polyangiitis in otolaryngologist practice: A review of current knowledge, Clin. Exp. Otorhinolar., 9, 8-13, doi:10.21053/ceo.2016.9.1.8, 2016.

Zimmermann, E. and Radespiel, U.: Species concepts, diversity, and evolution in primates: Lessons to be learned from mouse lemurs, Evol. Anthropol., 23, 11-14, doi:10.1002/evan.21388, 2014. 